\title{
Knowledge levels and awareness about rational antibiotic use and antimicrobial resistance before and after graduation: A cross-sectional study conducted in Malatya province, Turkey
}

Adem Kose ( $\nabla$ adem.kose@inonu.edu.tr)

Inonu University, Faculty of Medicine https://orcid.org/0000-0002-1853-1243

Cemil Colak

Inonu University School of Medicine: Inonu Universitesi Tip fakultesi

Research article

Keywords: Antimicrobial resistance, antibiotic, awareness, rational use

Posted Date: March 31st, 2021

DOl: https://doi.org/10.21203/rs.3.rs-365360/v1

License: (c) (1) This work is licensed under a Creative Commons Attribution 4.0 International License.

Read Full License

Version of Record: A version of this preprint was published at Infection and Drug Resistance on July 5th, 2021. See the published version at https://doi.org/10.2147/IDR.S317665. 


\section{Abstract}

Background Irrational use of antibiotics may adversely affect the treatment outcomes or even lead to increased antimicrobial resistance. We aimed to evaluate the level of theoretical knowledge of rational antibiotic use and awareness about antimicrobial resistance among the senior students at a medical school and the family physicians.

Methods This study was cross-sectional research and was carried out between 01 February-30 April 2019 in Malatya province. Two-hundred twenty-five senior students in the Inonu University Medical School (Group 1) and 230 actively-working family physicians in Malatya primary healthcare services who were found eligible (Group 2). Power analysis was calculated as the minimum of 240 participants when considering a proportion difference of 0.18 between the groups, a type I error of 0.05 and a type II error of 0.20 . A $p<0.05$ value was considered to be statistically significant.

Results Researchers argued that penal sanctions can be more effective by developing strict use policies to raise awareness of resistance to antimicrobials. Group 2 had higher self-confidence, and it was also concluded that they forgot their theoretical antibiotic knowledge over time, and they could not follow the current information because of the intensity of their working life. Both groups stated that post-graduation training could be used effectively for reducing antimicrobial resistance.

Conclusions This study attempted to increase awareness to determine the difference in theoretical knowledge levels and behavior models of physicians before and after graduation. Sustainable antibiotic training for doctors after graduation will contribute positive effects to antimicrobial resistance and rational use of antibiotics.

\section{Background}

Antibiotics are among the most commonly prescribed drugs. Modern medicine is closely linked to the rational use of antimicrobials to treat infections, but the emergence of antimicrobial-resistant (AMR) organisms threatens their presence for future generations (1). Irrational use of antibiotics is a serious problem throughout the world. The use of unnecessary antibiotics causes a heavy burden on the economy of developing countries, such as Turkey (2).

As a result of excessive and irrational use of antibiotics, resistance to bacteria to antibiotics is increasing all over the world, which has led to an increase in the cost of infection and a universal public health problem and also brings about high morbidity and mortality rates (3). The World Health Organization (WHO) reported that more than 25,000 people die each year because of infections that arise from resistant bacteria in European Hospitals resulting in a cost of approximately 1.5 billion Euros (4). Compared with Systemic Antimicrobial Consumption of European Countries (ESAC-Net), Turkey had the highest antibiotic use in Europe. Thus, the Turkish government already published a Rational Drug Use National Action Plan 20132017, with quantitative targets to reduce the use of antibiotics (5). The rate of irrational use of antibiotics is high among patients who apply to primary healthcare facilities in our 
country. The use of antimicrobial drugs is closely related to the knowledge, attitudes, and behavior of the physicians, as well as the antibiotic prescribing behavior of the healthcare professionals. All these factors contribute to the increase of AMR (6). The rapid increase in population, low socioeconomic level, and the differences in the theoretical knowledge of the physicians who prescribe antibiotics on rational principles of antibiotic use, and their attitudes and behaviors are only a few of the factors that may cause the rate of increase (7). The most important factor in starting antibiotic treatment for a patient is the presence of active infection and the evidence of its positive culture result. On the other hand, for the treatment of antibiotics that will be initiated in empirical terms with the diagnosis of infection, predicting the most probable factors that may cause infection is crucial (8). There are few studies on treatment of antibiotics in Turkey, which remained under-researched. Therefore, this study was conducted to understand the problems better and to offer solutions for irrational antibiotic use in Turkey.

In this study, we aimed to investigate antimicrobial prescribing habits and to evaluate the level of theoretical knowledge of rational antibiotic use and awareness about antimicrobial resistance among senior students of the medical school and family physicians in the Malatya province in Turkey.

\section{Methods}

\section{Study Design}

This study was carried out between 01 February-30 April 2019 in Malatya, which has approximately 750 thousand populations. This study survey was designed in line with the information obtained from various published research articles (9-11), and the form was prepared, including seven sections and twenty-eight questions. Section 1 consisted of data that included ages, gender, and professional experiences of groups. Section 2 consisted of four questions containing personal antibiotic use data. Section 3 consisted of three questions involving the decision to start antibiotic treatment. Section 4 consisted of nine questions relating to rational antibiotic use. Section 5 consisted of four questions related to antimicrobial resistance. Section 6 consisted of three questions related to antibiotic training before graduation from medical school. Section 7 consisted of five questions in the form of 'blanks-filling' regarding theoretical antibiotic knowledge.

The principles and purpose of this survey study were explained to all participants. The approval of all participants was taken orally and a consent form was signed by each participant. The informed, voluntary consent form for all participants in this study was received. Data were collected using face-toface interviews. The questionnaire started by keeping confidential of the names of the participants in this study. All of the answers were recorded. Then, the collected data were compared according to the groups.

\section{Power analysis}

Power analysis suggested a minimum of 120 senior students and 120 family physicians (totally minimum 240) when considering a proportion difference of 0.18 between the groups, a type I error of 0.05 
and a type II error of 0.20 . The number of the participants was calculated as a minimum seven-fold of each question in the questionnaire.

\section{Inclusion and Exclusion Criteria}

In this study, 225 senior students (group 1: the SS group) from Inonu University Medical School and 230 active-working family physicians in Malatya province (group 2: the FP group) were included. Students of other faculties other than the Inonu University Medical School, physicians who worked outside primary care services, specialist physicians from other branches other than family physicians, and physicians who were not active even if they had experience to work as a family physician were excluded from this study.

\section{Data Analysis}

The quantitative data were given as mean \pm standard deviation, and qualitative data were summarized as numbers with percentages. Normal distribution was checked using the Kolmogorov-Smirnov test. Qualitative data were analyzed by the Pearson Chi-Square test as appropriate. Comparison of proportions was made using the Bonferroni-adjusted Pearson Chi-Square test. A $p<0.05$ value was considered to be statistically significant. The IBM SPSS Statistics 26.0 software for Windows was used for analyses. A multilayer perceptron (MLP) artificial neural network model was used to identify the questions that may be effective in classifying the group variable (categories: senior students, family physicians). To build the proposed model, the data set examined was divided into two sets as training and testing. In this study, the questions that may be effective in classifying the group variable, which is accepted as the target variable, were estimated with the proposed model, and their significance levels were calculated in descending order.

\section{Results}

There were 455 participants in this study: group 1 had 225 (49.5\%), and group 2 had 230 (50.5\%) participants. In group 1, there were 92 males (40.9\%), 133 females (59.1\%) between 21-28 years of age; the mean age was $24 \pm 1$ years. In group 2, there were 153 males (66.5\%), 77 females (33.5\%) between 2566 years of age, and the mean age was $41 \pm 9$ years. The professional experience of group 2 was 32 (13.9\%) having 1-5 years, 45 (19.6\%) having 6-10 years, and 153 (66.5\%) having 11 years or more.

Table 1 presents the behaviors of the groups about personal antibiotic use and the decisions of the doctors in starting to antibiotics treatment for patients. As shown in Table 1, while Q2-3-5-6-7 were significantly different between groups $(p<0.001)$, the other questions were not statistically significant $(p>0.05)$.

- Q2: In which condition did you feel it necessary to start antibiotics the most?

- Q3: The way you took before you started antibiotics?

- Q5: The most important concern before an antibiotic prescription for a patient? 
- Q6: The most important finding that drives physicians mostly to prescribe?

- Q7: The most important finding-condition that drives physicians to prescribe?

The distribution of the questions related to the rational use of antibiotics is summarized in Table 2. As presented in Table 2, although the differences between the groups were significant concerning Q10-11-14$15(p<0.05)$, the differences between the groups were non-significant concerning other questions $(p>0.05)$.

- Q10: The most important principle in rational antibiotic using?

- Q11: Not having rational antibiotics use purpose?

- Q14: The most accurate definition of chemoprophylaxis purpose?

- Q15: Not among the surgical prophylaxis purposes?

The distribution of antimicrobial resistance and awareness, developing recommendations, and slogans for decreasing antimicrobial resistance and increasing awareness is given in Table 3. In Table 3, Q19-2021-23 were significantly different between the groups $(p<0.05)$; the remaining questions were not significantly different $(p>0.05)$.

- Q19: The most frequent reason for penicillin resistance in staphylococcl?

- Q20: How the national awareness of antimicrobials resistance can be increased?

- Q21: The adequacy of the education provided to you on antibiotics during medical education?

- Q23: What is your slogan about lowering the rate of antimicrobials resistance?

Table 4 indicates the data of the groups on answering the questions on antibiotic information (fill in the blanks questions). As shown in Table 4, Group 1 answered more questions, and the answers they gave were found to be more accurate.

Table 5 demonstrates three-year antibiotic consumption rates by years in primary healthcare services in Malatya province in Turkey. According to the e-prescription information system data of the Malatya Public Health Directorate, the rate of prescribing antibiotics tends to decrease in years in patients applying for primary healthcare services in Malatya (Table 5).

The importance values of the questions on the prediction of the groups are tabulated in Table 6. Among the questions, age was the most related variable (22.7\%) with the groups. The second most important variable after the age variable was determined as a professional experience with a rate of $11.9 \%$. On the other hand, the variable with the lowest significance value was obtained as gender with a rate of $0.1 \%$

\section{Discussion}

Increased antibiotics consumption and antimicrobial resistance are still significant problems in low socioeconomic countries (11). In our country, Turkey, the efforts have been made to reduce higher 
antibiotic consumption rates, to increase antimicrobial resistance awareness levels of physicians with training before and after graduation though raising the issue in writing/visual media, increasing the public awareness with public spots, and to prevent the non-prescribed sales of antibiotics in pharmacies since 2014.

One of the studies that was reported by Mahmood et al. (12) showed that the irrational antimicrobial use resulted in reduced quality of care, increased morbidity and mortality, and increased cases of adverse drug reactions and medication errors. Andrajati et al. (13) conducted a study though analyzing 788 oral prescriptions, which were prescribed by 28 doctors for acute pharyngitis and nonspecific respiratory infections at primary healthcare services, and 392 of them were evaluated for rationality according to local guidelines issued by Indonesian Ministry of Health. They found that 220 prescriptions for selecting the right antibiotic did not meet the rational antibiotic prescribing criteria. Besides, they concluded that training for rational antibiotic use and physician experience were the factors associated with the rationality of antibiotic prescriptions. Since viral agents play roles in the etiology of the common cold, antibiotics have no usage in its treatment; and resting and supportive treatments are adequate (14). We found that both groups had a sufficient level of awareness of this issue.

Practitioners sometimes cannot deal with their health problems in a detailed way because of their busy work schedules and they want to solve the problems in the most practical way (15). It may be argued that group 1 started antibiotics for simpler reasons. It was also possible to argue that the self-confidence of group 2 was higher than group 1 in making this decision, and group 1 was more cautious in this respect. These different approaches might be associated with the lack of self-confidence in the professional experience of the physicians or lack of adequate time rather than the presence of a healthcare employee in the place of residence and family. Given that the group 2 decided not to start antibiotics treatment, although it would necessarily cause more worries for themselves, and that the concerns of the group 2 being less might be explained by having more professional experience. The differences in knowledge, attitudes, and behaviors of physicians who prescribe antibiotics in primary healthcare facilities on deciding to start treatment and the necessity of treatment may also cause the rates of increase antibiotic prescription (16). The quality of a candidate physicians' pre-graduation training and the ability to apply this theoretical training in the master-apprentice or individual practice may significantly affect the attitude and behavior when starting antibiotics. Many factors may influence doctors' decisions, leading them to breach the principles of good clinical practice (17). For example, the fear of possible future complications in their patients or a desire to fulfill patients' expectations. Many physicians fear that they may miss out on the infection in the presence of leukocytosis, and often prefer to prescribe antibiotics to feel safe (18). In our study, the group 2 had more professional experience generally about antibiotics prescription in the presence of leukocytosis and argued the most important condition that forced primary healthcare physicians to write antibiotics is the lack of knowledge of these physicians. The physicians who had less experience believed that the presence of fever was more important, and the suspicion of infection that is not evidenced was the most important factor driving primary healthcare physicians to write antibiotics (19). Today, unfortunately, physicians can allocate less than optimal time to the patients for diagnosis 
because of an overcrowded patient for primary health care services and are often under pressure to prescribe antibiotics by patients and/or their relatives (20).

Among the most common causes of irrational antibiotic use, there is the expectation of the patient to prescribe an antibiotic from the physician considering "being a good doctor" equivalent to writing a prescription, insufficient examination facilities, and the need for the physician for feel safe by prescribing antibiotics by fearing that they might overlook an infection (21). The expectation of a patient to prescribe an antibiotic from the physician, keeping the equivalent of writing good medicine prescriptions, insufficient examination facilities, and the need for the physician to feel safe by prescribing antibiotics with the fear of distracting a possible infection are among the most common causes of irrational antibiotic use. (22). Another finding is that physicians forget their theoretical knowledge in time after they start active duty; they do not improve themselves, and follow update literature and developments because of their intensive work schedule (23). Group 1 thought that these reasons were more prominent in primary healthcare. Chemoprophylaxis is an optional procedure that is aimed to keep an infection with a high probability of development (24). The correct definition in this respect was made by group 1. Although there are guidelines released on surgical prophylaxis, we have witnessed misconduct in many clinics. The level of knowledge on surgical prophylaxis was low in both of our groups, and the possible cause of this might have been that they did not use it too much. Thus, the theoretical knowledge could be forgotten in time.

Antimicrobial resistance can be defined as the inefficiency of antibiotics in time due to the irrational/excessive use of antibiotics (25). The correct definition is made by group 1 at higher rates may be explained by that their theoretical knowledge is more recent. The most common reason for penicillin resistance in Staphylococci is the synthesis of a new PBP (Penicillin-Binding Protein) (26). Although nearly half of group 1 was thought in this way, more than half of group 2 believed that beta-lactamase was secreted, which was wrong. This finding may suggest that both groups are inadequate or do not update their knowledge of antimicrobial resistance mechanisms.

The presence of comorbid conditions and diseases must be considered in a patient who is scheduled to receive antibiotics. If an antibiotic drug that is initiated for the treatment of an infection is administered without considering comorbid diseases, it will inevitably lead to undesirable outcomes (27). The ability to answer the questions on comorbid conditions and diseases (e.g., pregnancy and renal failure) and the percentages of accurate answers were higher at a significant level in group 1. This may make us consider that group 2 forgets the theoretical knowledge in time and they are more likely to make mistakes. This subject shows the importance of transforming the antibiotic awareness in the basic pharmacology courses to the students in the early stages of school into knowledge that may also be used in the future (28). In this study, the most probable factors for the three most common primary healthcare groups were asked. The findings showed that the percentages of the rates of answering to questions and providing correct answers were low. Another interesting detail was that some of them in group 2 answered this question by writing the name antibiotics instead of the name of the agent by mistake and trying to answer the question more carelessly. 
The opinions and suggestions of the participants in the awareness of antimicrobial resistance were also of interest when planning the questionnaire. Among the suggestions that were included in our questionnaire, group 1 defended the idea that periodic training before and after graduation, developing strict usage policies and applying penal sanctions would be more effective; and the group 2 defended that the issue should be brought to the agenda in written and visual media more frequently, using public spots emphasizing antimicrobial resistance, and preparing brochures and posters would be more effective. A new generation of messages that encourage the first-choice use of narrow-spectrum antibiotics is needed, reflecting international efforts to preserve broad-spectrum antibiotic classes (29).

We have demonstrated the following conclusions: The levels of theoretical antibiotic knowledge are better in the pre-graduation period. After graduation, doctors ' theoretical knowledge of antibiotics is forgotten over time, and they are more likely to make mistakes. This situation has once again revealed the importance of education after graduation. The penal sanctions could be more effective by developing strict use policies to raise awareness of antimicrobial resistance. It could be said that they could not update their knowledge in this period due to the intensity in working life, and they forgot their theoretical knowledge of antibiotics over time. Especially training after graduation is crucial in reducing the excessive rates of antibiotic usage. This study could draw attention to increased antimicrobial resistance by highlighting the slogan which was put forward by Unal S et al. for the first time in 2014 at Hacettepe University in Ankara "Either awareness or resistance develops for antibiotics". This slogan may be useful for raising awareness against increased antimicrobial resistance. These results once again highlighted the need for immediate action of training and corrective actions.

The survey model used in this study was adapted from several similar studies that have been carried out before. It was applied to medical school senior students and family physicians to determine the differences between before and after graduation. If there were more participants, perhaps more accurate results could have been obtained, and more accurate analyses might have been performed.

\section{Conclusions}

This study may raise awareness to determine the difference in theoretical knowledge levels concerning antibiotics and behavior models of physicians before and after graduation and to reduce higher use rates to lower levels of antibiotics. Sustainable antibiotic training for the doctors after graduation will highly likely to contribute positively to antimicrobial resistance and the rational use of antibiotics. Further studies should be conducted with more participants.

\section{Declarations}

\section{Ethics approval and consent to participate}

This study was approved by the Non-Interventional Ethics Committee at Inonu University (Approval no: 2019/01-8). Another necessary permission for e-prescription information system data was obtained from 
the Public Health Unit of Malatya Provincial Healthcare Directorate (2019-1208). The informed, voluntary consent form for all participants in this study was received.

\section{Consent for publication}

Thanks to the heads of family physicians and senior students obtained informed consent from all participants

\section{Availability of data and materials}

The datasets used and/or analysed during the current study are available from the corresponding author on reasonable request

\section{Competing interests}

The authors declare that they have no competing interests.

\section{Funding}

This work was not supported by any extramural funding.

\section{Authors' Contributions}

All authors have read and approved the manuscript", and ensure that this is the case.

AK: Conceptualization, interventions to participant and collecting data, original draft preparation, writing and submitting

CC: Methodology, statistical analyses and final revision.

\section{Acknowledgements}

I would like to thank my teachers, Professor Yasar Bayındır and Professor Yasemin Ersoy, who contributed their valuable ideas in the thinking stage of this study.

\section{Authors' Information}

1. Department of Infectious Diseases and Clinical Microbiology, Faculty of Medicine, Inonu University, Malatya, Turkey.

2. Department of Biostatistics, and Medical Informatics, Faculty of Medicine, Inonu University, Malatya, Turkey.

\section{References}

1. Teixeira Rodrigues A, Roque F, Falcão A, Figueiras A, Herdeiro MT. Understanding physician antibiotic prescribing behaviour: a systematic review of qualitative studies. Int $J$ Antimicrob Agents. 
2013;41(3):203-12.

2. Okyay RA, Erdogan A. Self-medication practices and rational drug use habits among university students: a cross-sectional study from Kahramanmaras, Turkey. PeerJ. 2017(1);5:e3990.

3. Bell BG, Schellevis F, Stobberingh E, Goossens H, Pringle M. A systematic review and meta-analysis of the effects of antibiotic consumption on antibiotic resistance. BMC Infect Dis. 2014;14:13.

4. Wozniak TM, Barnsbee L, Lee XJ, Pacella RE. Using the best available data to estimate the cost of antimicrobial resistance: a systematic review. Antimicrob Resist Infect Control. 2019 Feb 1;8:26. doi: 10.1186/s13756-019-0472-z.

5. Versporten A, Bolokhovets G, Ghazaryan L, Abilova V, Pyshnik G, Spasojevic T, Korinteli I, Raka L, Kambaralieva B, Cizmovic L, Carp A, Radonjic V, Maqsudova N, Celik HD, Payerl-Pal M, Pedersen HB, Sautenkova N, Goossens H, WHO/Europe-ESAC Project Group. Antibiotic use in eastern Europe: a cross-national database study in coordination with the WHO Regional Office for Europe. Lancet Infect Dis. 2014;14(5):381-7.

6. Gualano MR, Gili R, Scaioli G, Bert F, Siliquini R. General population's knowledge and attitudes about antibiotics: a systematic review and meta-analysis. Pharmacoepidemiol and Drug Saf. 2015;24(1):210.

7. Wright EP, Jain P. Survey of antibiotic knowledge amongst final year medical students. $J$ Antimicrob Chemother. 2004;53(3):550-1.

8. Leekha S, Terrell CL, Edson RS. General Principles of Antimicrobial Therapy. Mayo Clin Proc. 2011;86(2):156-67.

9. Lukačišinová, Marta; Fernando, Booshini; Bollenbach, Tobias. Highly parallel lab evolution reveals that epistasis can curb the evolution of antibiotic resistance. Nature communications, 2020, 11.1: 114.

10. Porse, A., Jahn, L. J., Ellabaan, M. M., \& Sommer, M. O. Dominant resistance and negative epistasis can limit the co-selection of de novo resistance mutations and antibiotic resistance genes. Nature communications, 2020, 11.1: 1-9.

11. Steffensen FH, Schønheyder HC, Sørensen HT. High prescribers of antibiotics among general practitioners-relation to prescribing habits of other drugs and use of microbiological diagnostics. Scand J Infect Dis. 1997;29(4):409-13.

12. Mahmood A, Elnour AA, Ali AA, Hassan NA, Shebab A, Bhagavathula AS. Evaluation of rational use of medicines (RUM) in four government hospitals in UAE. Saudi Pharm J. 2016;24(2):189-96.

13. Andrajati R, Tilaqza A, Supardi S. Factors related to rational antibiotic prescriptions in community health centers in Depok City, Indonesia. J of Infect and Public Health 2017;10(1):41-8.

14. Troullos E, Baird L, Jayawardena S. Common cold symptoms in children: results of an Internet-based surveillance program. J Med Internet Res. 2014;16(6):e144.

15. Dugdale DC, Epstein R, Pantilat SZ. Time and the Patient-Physician Relationship. J Gen Intern Med. 1999;14(Suppl 1):S34-40. 
16. Alothman A, Algwizani A, Alsulaiman M, Alalwan A, Binsalih S, Bosaeed M. Knowledge and Attitude of Physicians Toward Prescribing Antibiotics and the Risk of Resistance in Two Reference Hospitals. Infect Dis (Auckl). 2016;9:33-38.

17. Seid MA, Hussen MS. Knowledge and attitude towards antimicrobial resistance among final year undergraduate paramedical students at University of Gondar, Ethiopia. BMC Infect Dis. 2018;18(1):312.

18. Ayranci U, Akgun Y, Unluoglu I, Kiremitci A. Antibiotic prescribing patterns for sore throat infections in a university-based primarycare clinic. Ann Saudi Med. 2005;25(1):22-8.

19. Dallas A, van Driel M, Morgan S, Tapley A, Henderson K, Ball J, Oldmeadow C, Davey A, Mulquiney K, Davis J, Spike N, McArthur L, Magin P. Antibiotic prescribing for sore throat: a cross-sectional analysis of the ReCEnT study exploring the habits of early-career doctors in family practice. Fam Pract. 2016;33(3):302-8.

20. O’Doherty J, Leader LFW, O’Regan A, Dunne C, Puthoopparambil SJ, O'Connor R. Over prescribing of antibiotics for acute respiratory tract infections; a qualitative study to explore Irish general practitioners' perspectives. BMC Fam Pract. 2019;20(1):27.

21. Axente C, Licker M, Moldovan R, Hogea E, Muntean D, Horhat F, Bedreag O, Sandesc D, Papurica M, Dugaesescu D, Voicu M, Baditoiu L. Antimicrobial consumption, costs and resistance patterns: a two year prospective study in a Romanian intensive care unit. BMC Infect Dis. 2017 May 22;17(1):358. doi: 10.1186/s12879-017-2440-7.

22. Masoud A, Noori Hekmat S, Dehnavieh R, Haj-Akbari N, Poursheikhali A, Abdi Z. An Investigation of Prescription Indicators and Trends Among General Practitioners and Specialists From 2005 to 2015 in Kerman, Iran. Int J Health Policy Manag. 2018 Sep 1;7(9):818-827. doi: 10.15171/ijhpm.2018.28.

23. Patel VL, Shortliffe EH, Stefanelli M, Szolovits P, Berthold MR, Bellazzi R, Abu-Hanna A. The coming of age of artificial intelligence in medicine. Artif Intell Med. 2009;46(1):5-17.

24. McBride WJ. Chemoprophylaxis of Tropical Infectious Diseases. Pharmaceuticals (Basel). 2010 May 18;3(5):1561-1575.

25. Aslam B, Wang W, Arshad MI, Khurshid M, Muzammil S, Rasool MH, Nisar MA, Alvi RF, Aslam MA, Qamar MU, Salamat MKF, Baloch Z. Antibiotic resistance: a rundown of a global crisis. Infect Drug Resist. 2018;11:1645-1658.

26. Buroni S, Pollini S, Rossolini GM, Perrin E. Editorial: Evolution of Genetic Mechanisms of Antibiotic Resistance. Front Genet. 2019 Oct 11;10:983.

27. Llor C, Bjerrum L. Antimicrobial resistance: risk associated with antibiotic overuse and initiatives to reduce the problem. Ther Adv Drug Saf. 2014;5(6):229-41.

28. Pulcini C, Gyssens IC. How to educate prescribers in antimicrobial stewardship practices. Virulence. 2013 Feb 15;4(2):192-202. doi: 10.4161/viru.23706.

29. Huttner B, Saam M, Moja L, Mah K, Sprenger M, Harbarth S, Magrini N. How to improve antibiotic awareness campaigns: findings of a WHO global survey. BMJ Glob Health. 2019 May 9;4(3):e001239. doi: 10.1136/bmjgh-2018-00123. 
Table 1. The behaviors of the groups about personal antibiotic use and the doctors'decisions in starting to antibiotics treatment for patients.

\begin{tabular}{|c|c|c|c|c|c|c|c|}
\hline \multirow[b]{2}{*}{$\begin{array}{l}\text { Question } \\
\text { Number }\end{array}$} & \multirow[b]{2}{*}{ Questions } & \multirow[b]{2}{*}{ Options } & \multicolumn{2}{|c|}{ Group 1} & \multicolumn{2}{|c|}{ Group 2} & \multirow{2}{*}{$\mathrm{p}^{*}$ value } \\
\hline & & & $\begin{array}{l}\text { Number } \\
(n=225)\end{array}$ & $\begin{array}{c}\text { Column } \\
\%\end{array}$ & $\begin{array}{l}\text { Number } \\
(\mathbf{n}=\mathbf{2 3 0})\end{array}$ & $\begin{array}{c}\text { Column } \\
\%\end{array}$ & \\
\hline 1 & $\begin{array}{l}\text { When did you last use antibiotics for } \\
\text { yourself? }\end{array}$ & $\begin{array}{l}\text { within the last } 1 \text { week } \\
\text { within the last } 1 \text { month } \\
\text { within the last } 6 \text { months } \\
\text { I never used within the last } 1 \text { year }\end{array}$ & $\begin{array}{c}7 \\
19 \\
90 \\
109\end{array}$ & $\begin{array}{c}3.1 \\
8.4 \\
40.0 \\
48.5\end{array}$ & $\begin{array}{c}9 \\
26 \\
93 \\
102\end{array}$ & $\begin{array}{c}3.9 \\
11.3 \\
40.4 \\
44.4 \\
\end{array}$ & 0.67 \\
\hline 2 & $\begin{array}{l}\text { In which condition did you feel that it was } \\
\text { necessary to start antibiotics the most? }\end{array}$ & $\begin{array}{l}\text { High fever } \\
\text { Sore throat } \\
\text { Prolonged cough and sputum excretion period } \\
\text { Diarrhea }\end{array}$ & $\begin{array}{l}63 \\
74 \\
75 \\
13\end{array}$ & $\begin{array}{c}28.0 \\
34.9 \\
33.3 \\
5.8\end{array}$ & $\begin{array}{c}81 \\
35 \\
106 \\
8\end{array}$ & $\begin{array}{c}35.2 \\
15.2 \\
46.1 \\
3.5\end{array}$ & $<0.001$ \\
\hline 3 & $\begin{array}{l}\text { The way you took before you started } \\
\text { antibiotics? }\end{array}$ & $\begin{array}{l}\text { I saw the physician, I used that was prescribed in line with my diagnosis. } \\
\text { I started that I had at home and that I thought would be suitable. } \\
\text { I purchased from the pharmacy without a prescription saying I was a physician. } \\
\text { I took from my friends/family members upon their recommendations. }\end{array}$ & $\begin{array}{c}183 \\
33 \\
4 \\
5\end{array}$ & $\begin{array}{l}81.3 \\
14.7 \\
1.8 \\
2.2\end{array}$ & $\begin{array}{c}135 \\
83 \\
11 \\
1\end{array}$ & $\begin{array}{c}58.7 \\
36.1 \\
4.8 \\
0.4\end{array}$ & $<0.001$ \\
\hline 4 & $\begin{array}{l}\text { Your behavior in the process when you } \\
\text { started antibiotics treatment? }\end{array}$ & $\begin{array}{l}\text { I use it in the first 1-2 days and then I stop using it when my symptoms recover. } \\
\text { I try to use it; however, I quit using it when I see the slightest side effect. } \\
\text { I try to complete the treatment process under any conditions. } \\
\text { When prescribing, I never start them, I try to find altemative solutions. }\end{array}$ & $\begin{array}{c}27 \\
38 \\
152 \\
8\end{array}$ & $\begin{array}{l}12.0 \\
16.9 \\
67.6 \\
3.6\end{array}$ & $\begin{array}{l}18 \\
32 \\
170 \\
10\end{array}$ & $\begin{array}{c}7.8 \\
13.9 \\
73.9 \\
4.3\end{array}$ & 0.32 \\
\hline 5 & $\begin{array}{l}\text { The biggest concem before an antibiotic } \\
\text { prescription for a patient? }\end{array}$ & $\begin{array}{l}\text { Starting them even if it is not necessary. } \\
\text { Not starting them even if it is not necessary. } \\
\text { Selecting a drug from the inappropriate antibiotic class. } \\
\text { Overlooking important features of the drug and the patient. }\end{array}$ & $\begin{array}{l}83 \\
45 \\
40 \\
57\end{array}$ & $\begin{array}{l}36.9 \\
20.0 \\
17.8 \\
25.3\end{array}$ & $\begin{array}{l}131 \\
39 \\
14 \\
46\end{array}$ & $\begin{array}{c}57.0 \\
17.0 \\
6.1 \\
19.9\end{array}$ & $<0.001$ \\
\hline 6 & $\begin{array}{l}\text { The most important finding that drives } \\
\text { physicians mostly to prescribe? }\end{array}$ & $\begin{array}{l}\text { CRP elevation } \\
\text { Presence of pyuria } \\
\text { Presence of fever } \\
\text { Leukocytosis }\end{array}$ & $\begin{array}{l}66 \\
40 \\
84 \\
34\end{array}$ & $\begin{array}{l}29.3 \\
17.8 \\
37.3 \\
15.1\end{array}$ & $\begin{array}{l}57 \\
32 \\
61 \\
80\end{array}$ & $\begin{array}{l}24.8 \\
13.9 \\
26.5 \\
34.8\end{array}$ & $<0.001$ \\
\hline 7 & $\begin{array}{l}\text { The most important condition that drives } \\
\text { physicians to prescribe? }\end{array}$ & $\begin{array}{l}\text { Suspicion of unproven infection } \\
\text { Pressure of the patients or his/her relatives on the physician } \\
\text { The desire of the physician to feel secure } \\
\text { Inadequate knowledge level of the physician on the infection }\end{array}$ & $\begin{array}{l}39 \\
63 \\
78 \\
45\end{array}$ & $\begin{array}{l}17.3 \\
28.0 \\
34.7 \\
20.0\end{array}$ & $\begin{array}{l}96 \\
65 \\
50 \\
19\end{array}$ & $\begin{array}{c}41.7 \\
28.3 \\
21.7 \\
8.3\end{array}$ & $<0.001$ \\
\hline 8 & $\begin{array}{l}\text { The most significant feature of the } \\
\text { antibiotics in the preferences of the } \\
\text { physicians in prescribing? }\end{array}$ & $\begin{array}{l}\text { Spectrum } \\
\text { Effect mechanism } \\
\text { Ease of use } \\
\text { Penetration to infection tissue being good }\end{array}$ & $\begin{array}{c}106 \\
38 \\
9 \\
72\end{array}$ & $\begin{array}{c}47.1 \\
16.9 \\
4.0 \\
32.0\end{array}$ & $\begin{array}{l}109 \\
29 \\
11 \\
81\end{array}$ & $\begin{array}{c}47.4 \\
12.6 \\
4.8 \\
35.2\end{array}$ & 0.59 \\
\hline 9 & The most vital criterion to start? & $\begin{array}{l}\text { The patients' fever } \\
\text { Acute phase reactants being high } \\
\text { Having a positive culture result } \\
\text { The disrupted hemodynamics in the patient }\end{array}$ & $\begin{array}{c}5 \\
9 \\
202 \\
9\end{array}$ & $\begin{array}{c}2.2 \\
4.0 \\
89.8 \\
4.0\end{array}$ & $\begin{array}{c}7 \\
12 \\
206 \\
5\end{array}$ & $\begin{array}{c}3.0 \\
5.2 \\
89.6 \\
2.2\end{array}$ & 0.59 \\
\hline
\end{tabular}

*: Pearson's chi-square test; the data are given as a number (percentage)

Table 2. The distribution of the questions related to the rational use of antibiotics

\begin{tabular}{|c|c|c|c|c|c|c|c|}
\hline \multirow[b]{2}{*}{$\begin{array}{l}\text { Question } \\
\text { Number }\end{array}$} & \multirow[b]{2}{*}{ Questions } & \multirow[b]{2}{*}{ Options } & \multicolumn{2}{|c|}{ Group 1} & \multicolumn{2}{|c|}{ Group 2} & \multirow{2}{*}{$\begin{array}{c}\mathbf{p}^{*} \\
\text { value }\end{array}$} \\
\hline & & & $\begin{array}{l}\text { Number } \\
(\mathrm{n}=\mathbf{2 2 5})\end{array}$ & $\begin{array}{c}\text { Column } \\
\%\end{array}$ & $\begin{array}{l}\text { Number } \\
(\mathrm{n}=\mathbf{2 3 0})\end{array}$ & $\begin{array}{c}\text { Column } \\
\%\end{array}$ & \\
\hline \multirow[t]{4}{*}{10} & \multirow{4}{*}{$\begin{array}{l}\text { The most important principle in } \\
\text { rational antibiotic using? }\end{array}$} & Presence of infection that requires antibiotics use & 206 & 91.6 & 215 & 93.5 & \multirow{4}{*}{0.03} \\
\hline & & General condition of the patient & 9 & 4.0 & 10 & 4.3 & \\
\hline & & Presence of immunosuppression & 9 & 4.0 & 1 & 0.4 & \\
\hline & & Recent infection history & 1 & 0.4 & 4 & 1.8 & \\
\hline \multirow[t]{4}{*}{11} & \multirow{4}{*}{$\begin{array}{l}\text { Not having a rational antibiotics } \\
\text { use purpose? }\end{array}$} & Common cold treatment & 207 & 92.0 & 198 & 86.1 & \multirow{4}{*}{0.006} \\
\hline & & Simple cystitis treatment & 8 & 3.6 & 4 & 1.7 & \\
\hline & & Treatment of opportunistic infections & 8 & 3.6 & 22 & 9.6 & \\
\hline & & Treatment of invasive diarrhea & 2 & 0.8 & 6 & 2.6 & \\
\hline \multirow[t]{4}{*}{12} & \multirow{4}{*}{$\begin{array}{l}\text { The most important purpose of } \\
\text { empirical using? }\end{array}$} & Having a wide spectrum & 54 & 24.0 & 57 & 24.8 & \multirow{4}{*}{0.44} \\
\hline & & Having a narrow spectrum & 2 & 0.9 & 7 & 3.0 & \\
\hline & & Covering the most probable infection factors & 165 & 73.3 & 162 & 70.4 & \\
\hline & & Including combined treatment as much as possible & 4 & 1.8 & 4 & 1.7 & \\
\hline \multirow[t]{4}{*}{13} & \multirow{4}{*}{$\begin{array}{l}\text { The most important purpose of } \\
\text { combined using? }\end{array}$} & The desire for keeping the infection under control as soon as possible & 91 & 40.4 & 104 & 45.2 & \multirow{4}{*}{0.59} \\
\hline & & Reducing toxicity & 8 & 3.6 & 11 & 4.8 & \\
\hline & & Expanding the targeted active microorganism group & 100 & 44.4 & 93 & 40.4 & \\
\hline & & Bringing the active plasma concentration to the highest level & 26 & 11.6 & 22 & 9.6 & \\
\hline \multirow[t]{5}{*}{14} & \multirow{5}{*}{$\begin{array}{l}\text { The most accurate definition of } \\
\text { chemoprophylaxis purpose? }\end{array}$} & An optional process to prevent an infection with a high risk of & 153 & 68.3 & 120 & 52.2 & \multirow{5}{*}{0.003} \\
\hline & & progression & 23 & 10.3 & 40 & 17.4 & \\
\hline & & A routine process in an endemic area & 29 & 12.9 & 35 & 15.2 & \\
\hline & & A compulsory process in an endemic area & 20 & 8.5 & 35 & 15.2 & \\
\hline & & A protective process for diseases with high mortality risk & & & & & \\
\hline \multirow[t]{4}{*}{15} & \multirow{4}{*}{$\begin{array}{l}\text { Not among the surgical } \\
\text { prophylaxis purposes? }\end{array}$} & Preventing surgical site infections & 13 & 5.8 & 21 & 9.1 & \multirow{4}{*}{0.04} \\
\hline & & Reducing postoperative infectious morbidity and mortality & 33 & 14.7 & 33 & 14.3 & \\
\hline & & Absolutely starting for all patients that undergo surgery & 96 & 42.7 & 85 & 37.0 & \\
\hline & & Avoiding negative changes in the patient/hospital microorganism flora & 83 & 36.8 & 91 & 39.6 & \\
\hline \multirow[t]{4}{*}{16} & \multirow{4}{*}{$\begin{array}{l}\text { The thing you want to hear most } \\
\text { from the representative of a drug } \\
\text { company? }\end{array}$} & Emphasizing the efficacy and indications & 92 & 40.9 & 93 & 40.4 & \multirow{4}{*}{0.93} \\
\hline & & Supporting the introduction with previously conducted scientific & 90 & 40.0 & 88 & 38.3 & \\
\hline & & clinical studies & 40 & 17.8 & 45 & 19.6 & \\
\hline & & $\begin{array}{l}\text { Emphasizing the ease of use, and the side effects and drug interactions } \\
\text { Supporting the presentation with medical and paramedical } \\
\text { ingredients/promises }\end{array}$ & 3 & 1.3 & 4 & 1.7 & \\
\hline
\end{tabular}

*: Pearson's chi-square test; the data are given as a number (percentage) 
Table 3. The distribution of the antimicrobial resistance and awareness, developing recommendations and slogans for decreasing antibiotic resistance and increasing awareness.

\begin{tabular}{|c|c|c|c|c|c|c|c|}
\hline \multirow[b]{2}{*}{$\begin{array}{l}\text { Question } \\
\text { Number }\end{array}$} & \multirow[b]{2}{*}{ Questions } & \multirow[b]{2}{*}{ Options } & \multicolumn{2}{|c|}{ Group 1} & \multicolumn{2}{|c|}{ Group 2} & \multirow{2}{*}{$\begin{array}{c}\mathbf{p}^{*} \\
\text { value }\end{array}$} \\
\hline & & & $\begin{array}{c}\text { Number } \\
(\mathrm{n}=225)\end{array}$ & $\underset{\%}{\text { Column }}$ & $\begin{array}{c}\text { Number } \\
(\mathrm{n}=230)\end{array}$ & $\underset{\%}{\text { Column }}$ & \\
\hline \multirow[t]{4}{*}{17} & The most important condition that & High costs and economic losses & 9 & 4.0 & 10 & 4.3 & \\
\hline & may occur as a result of irrational & Severe side effects and toxicity & 18 & 8.0 & 18 & 7.8 & 0.99 \\
\hline & using? & Possible drug interactions with other drugs & 5 & 2.2 & 5 & 2.2 & \\
\hline & & Antimicrobial resistance & 193 & 85.8 & 197 & 85.7 & \\
\hline \multirow[t]{4}{*}{18} & What is antibiotic resistance? & Suppression and elimination of microbial flora & 9 & 4.0 & 10 & 4.3 & \\
\hline & & Narrow-spectrum antibiotics being of no use & 44 & 19.6 & 28 & 12.2 & 0.06 \\
\hline & & The necessity of using wide-spectrum antibiotics under any conditions & 13 & 5.8 & 7 & 3.0 & \\
\hline & & The inactivation of antibiotics with irrational antibiotics use & 159 & 70.7 & 185 & 804 & \\
\hline \multirow[t]{4}{*}{19} & The most frequent reason for & The secretion of B-lactamase enzyme & 95 & 42.2 & 117 & 50.9 & \\
\hline & penicillin resistance in & Modifying enzymes & 9 & 4.0 & 11 & 4.8 & 0.02 \\
\hline & staphylococci? & Decrease in membrane permeability & 7 & 3.1 & 4 & 1.7 & \\
\hline & & Acquisition of a new PBP (Penicillin Binding Protein) & 114 & 50.7 & 98 & 42.6 & \\
\hline \multirow[t]{4}{*}{20} & How can the national awareness of & By bringing it to the written and visual media frequently & 64 & 28.4 & 83 & 36.1 & \\
\hline & antibiotics resistance be increased? & By preparing public spots, brochures and posters on antibiotics resistance & 46 & 20.4 & 64 & 27.8 & 0.007 \\
\hline & & By providing periodical training to physicians before/after graduation & 44 & 19.6 & 39 & 17.0 & \\
\hline & & By developing strict use policies and applying a penal sanction & 71 & 31.6 & 44 & 19.1 & \\
\hline \multirow[t]{4}{*}{21} & The adequacy of the education & Yes & 43 & 19.1 & 66 & 28.7 & \\
\hline & provided to you on antibiotics during & No & 83 & 36.9 & 75 & 32.6 & 0.048 \\
\hline & medical education? & Partly & 89 & 39.6 & 85 & 37.0 & \\
\hline & & No idea/I do not want to explain & 10 & 4.4 & 4 & 1.7 & \\
\hline \multirow[t]{4}{*}{22} & Method of the habit of prescribing & By actively examining patients especially in senior students in clinics & 145 & 64.4 & 135 & 58.7 & \\
\hline & the most accurate by a physician who & By writing prescriptions over yirtual patient scenarios & 54 & 240 & 63 & 274 & \\
\hline & is about to graduate? & By memorizing the prescriptions on the Internet/written sources & 3 & 1.3 & 6 & 2.6 & 0.54 \\
\hline & & By adopting the prescription habits of the assistants/lecturers & 23 & 10.3 & 26 & 11.3 & \\
\hline \multirow[t]{4}{*}{23} & What is your slogan about lowering & Either awareness or resistance develops for antibiotics & 156 & 69.3 & 163 & 70.9 & \\
\hline & the rate of antibiotics resistance? & Unawareness antibiotic use kills & 48 & 21.3 & 39 & 17.0 & 0.034 \\
\hline & & Do not touch my antibiotics & 9 & 4.0 & 3 & 1.3 & \\
\hline & & Other & 12 & 5.4 & 25 & 10.8 & \\
\hline
\end{tabular}

*: Pearson's chi-square test; the data are given as number (percentage)

Table 4. Data of the groups on answering the questions on antibiotic information (fill in the blanks).

\begin{tabular}{|c|c|c|c|c|c|c|c|c|c|c|c|}
\hline \multirow[b]{2}{*}{$\begin{array}{l}\text { Question } \\
\text { Number }\end{array}$} & \multirow[b]{2}{*}{ Questions* } & \multirow[b]{2}{*}{$\begin{array}{l}\text { Answering } \\
\text { Questions }\end{array}$} & \multicolumn{2}{|c|}{ Group 1} & \multicolumn{2}{|c|}{ Group 2} & \multirow[b]{2}{*}{$\begin{array}{l}\text { Correct } \\
\text { Answers }\end{array}$} & \multicolumn{2}{|c|}{ Group 1} & \multicolumn{2}{|c|}{ Group 2} \\
\hline & & & $\begin{array}{l}\text { Number } \\
(n=225)\end{array}$ & $\begin{array}{l}\text { Rate } \\
(\%)\end{array}$ & $\begin{array}{c}\text { Number } \\
(n=230)\end{array}$ & $\begin{array}{l}\text { Rate } \\
(\%)\end{array}$ & & $\begin{array}{c}\text { Number } \\
(n=225)\end{array}$ & $\begin{array}{l}\text { Rate } \\
(\%)\end{array}$ & $\begin{array}{c}\text { Number } \\
(n=230)\end{array}$ & $\begin{array}{l}\text { Rate } \\
(\%)\end{array}$ \\
\hline \multirow[t]{4}{*}{24} & Three antibiotics groups that are & Zero answer & $3 a$ & 1.3 & $32 \mathrm{~b}$ & 13.9 & Zero correct & $6 a^{*}$ & 2.7 & $35 b^{* *}$ & 15.2 \\
\hline & contraindicated during pregnancy. & One group & $10 \mathrm{a}$ & 4.4 & $9 \mathrm{a}$ & 3.9 & One correct & $29 \mathrm{a}$ & 12.9 & $26 \mathrm{a}$ & 11.3 \\
\hline & & Two groups & $49 \mathrm{a}$ & 21.7 & $24 \mathrm{~b}$ & 10.4 & Two correct & $88 \mathrm{a}$ & 39.1 & $74 a$ & 32.2 \\
\hline & & All groups & $163 \mathrm{a}$ & 72.6 & $165 \mathrm{a}$ & 71.8 & All correct & $102 \mathrm{a}$ & 45.3 & $95 \mathrm{a}$ & 41.3 \\
\hline \multirow[t]{4}{*}{25} & Three antibiotics group that require & Zero answer & $19 \mathrm{a}$ & 8.4 & $52 \mathrm{~b}$ & 22.6 & Zero correct & $19 \mathrm{a}$ & 8.4 & $68 \mathrm{~b}$ & 29.6 \\
\hline & dose adjustment in renal failure. & One group & $36 a$ & 16.0 & $15 \mathrm{~b}$ & 6.5 & One correct & $53 a$ & 23.6 & $83 \mathrm{~b}$ & 36.1 \\
\hline & & Two groups & $51 \mathrm{a}$ & 22.7 & $35 \mathrm{~b}$ & 15.2 & Two correct & $64 a$ & 28.4 & $62 \mathrm{a}$ & 26.9 \\
\hline & & All groups & $119 \mathrm{a}$ & 52.9 & $128 \mathrm{a}$ & 55.7 & All correct & $89 \mathrm{a}$ & 39.6 & $17 \mathrm{~b}$ & 7.4 \\
\hline \multirow[t]{4}{*}{26} & Three antibiotics group that cause cell & Zero answer & $14 a$ & 6.2 & $56 \mathrm{~b}$ & 24.4 & Zero correct & $15 \mathrm{a}$ & 6.7 & $61 \mathrm{~b}$ & 26.5 \\
\hline & wall synthesis inhibition. & One group & $18 \mathrm{a}$ & 8.0 & $7 \mathrm{~b}$ & 3.0 & One correct & $29 \mathrm{a}$ & 12.9 & $20 \mathrm{a}$ & 8.7 \\
\hline & & Two groups & $53 a$ & 23.6 & $27 \mathrm{~b}$ & 11.7 & Two correct & $71 \mathrm{a}$ & 31.5 & $55 \mathrm{a}$ & 23.9 \\
\hline & & All groups & $140 \mathrm{a}$ & 62.2 & $140 \mathrm{a}$ & 60.9 & All correct & $110 \mathrm{a}$ & 48.9 & $94 a$ & 40.9 \\
\hline \multirow[t]{3}{*}{27} & Two antibiotics that may be used in & Zero antibiotics & $31 \mathrm{a}$ & 13.8 & $42 \mathrm{a}$ & 18.2 & Zero correct & $83 a$ & 36.9 & $93 a$ & 40.4 \\
\hline & surgical prophylaxis. & One antibiotics & $54 a$ & 24.0 & $26 \mathrm{~b}$ & 11.3 & One correct & $90 \mathrm{a}$ & 40.0 & $67 \mathrm{~b}$ & 29.1 \\
\hline & & Two antibiotics & $140 \mathrm{a}$ & 62.2 & $162 \mathrm{a}$ & 70.5 & Two correct & $52 \mathrm{a}$ & 23.1 & $70 \mathrm{a}$ & 30.5 \\
\hline \multirow[t]{5}{*}{28} & The most frequent factors of acute & Zero factor & $14 a$ & 6.2 & $59 \mathrm{~b}$ & 25.7 & Zero correct & $9 \mathrm{a}$ & 4.0 & $43 \mathrm{~b}$ & 18.7 \\
\hline & cryptic tonsillitis, simple acute & One factor & $3 a$ & 1.3 & $4 a$ & 1.7 & One correct & $8 a$ & 3.6 & $15 \mathrm{a}$ & 6.5 \\
\hline & cystitis, and community-acquired & Two factors & $8 \mathrm{a}$ & 3.6 & $8 \mathrm{a}$ & 3.4 & Two correct & $57 \mathrm{a}$ & 25.3 & $45 \mathrm{a}$ & 19.6 \\
\hline & pneumonia. & All factors & $200 \mathrm{a}$ & 88.8 & $159 b$ & 69.2 & All correct & $142 \mathrm{a}$ & 63.1 & $103 \mathrm{~b}$ & 44.8 \\
\hline & & & & & & & Mistakenly & $9 \mathrm{a}$ & 4.0 & $24 \mathrm{~b}$ & 10.4 \\
\hline
\end{tabular}

Different letters $(\mathrm{a}, \mathrm{b})$ in each row show a statistically significant difference $(\mathrm{p}<0.05$; Bonferroni-corrected Pearson's chi-square test)

Table 5. Three-year antibiotic consumption rates by years in primary healthcare services in Malatya province in Turkey.

\begin{tabular}{lccc} 
Years & Total prescription numbers & Number of prescriptions written antibiotics & Rates (\%) \\
\hline 2016 & 1.150 .674 & 349.607 & 30.04 \\
2017 & 1.274 .435 & 342.313 & 26.85 \\
2018 & 1.357 .365 & 361.737 & 26.64 \\
\hline
\end{tabular}


Table 6. Importance values of the questions on the prediction of the groups based on the MLP model.

\begin{tabular}{|c|c|c|c|}
\hline Variables & Importance & Variables & Importance \\
\hline Ages & $22.7 \%$ & Q 12 & $1.5 \%$ \\
\hline Professional experience & $11.9 \%$ & Q 28/2 & $1.5 \%$ \\
\hline $\mathrm{Q} 25 / 2$ & $3.1 \%$ & Q 14 & $1.5 \%$ \\
\hline Q 27/1 & $3.1 \%$ & Q 21 & $1.4 \%$ \\
\hline Q 24/2 & $3.0 \%$ & Q 11 & $1.4 \%$ \\
\hline Q 7 & $2.8 \%$ & Q9 & $1.4 \%$ \\
\hline Q 28/1 & $2.7 \%$ & Q 17 & $1.3 \%$ \\
\hline Q $24 / 3$ & $2.6 \%$ & Q 18 & $1.1 \%$ \\
\hline Q 26/1 & $2.4 \%$ & Q 23 & $1.1 \%$ \\
\hline Q 15 & $2.4 \%$ & Q 13 & $1.1 \%$ \\
\hline Q 27/2 & $2.3 \%$ & Q 10 & $1.1 \%$ \\
\hline Q 25/1 & $2.3 \%$ & Q 8 & $1.0 \%$ \\
\hline Q 28/3 & $2.3 \%$ & Q 22 & $0.9 \%$ \\
\hline Q 26/2 & $2.2 \%$ & Q 5 & $0.9 \%$ \\
\hline Q 4 & $2.2 \%$ & Q 2 & $0.8 \%$ \\
\hline Q 26/3 & $2.0 \%$ & Q 20 & $0.7 \%$ \\
\hline Q 3 & $1.8 \%$ & Q 19 & $0.7 \%$ \\
\hline Q 25/3 & $1.7 \%$ & Q 6 & $0.7 \%$ \\
\hline Q 24/1 & $1.7 \%$ & Q 1 & $0.3 \%$ \\
\hline Q 16 & $1.5 \%$ & Gender & $0.1 \%$ \\
\hline
\end{tabular}

